\title{
TRANSCREATIVE JOYCE
}

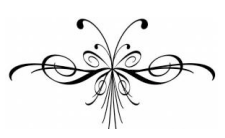

\section{Rosa MARIA BolLetTIERI BosinelLI}

The focus of this dossier - multilingual transformations in
Joyce - is directly related to Joyce's peculiar use of English
as a translatable and translated idiom. Joyce's writing strategies have much in common with the process of translation, not so much in terms of bridging the gap between two different languages and cultures (although even this aspect is present in his multi-faceted style), but specifically in terms of transforming a commonplace meaning into something new and unexpected. ${ }^{1}$ I have called this process "transcreation", following a notion that has recently entered the field of translation studies. ${ }^{2}$ The term was coined long ago with reference to the creative translation of the Bible in order to make it accessible all over India. As Di Giovanni puts it:

\footnotetext{
${ }^{1}$ These introductory comments are extracted from my "James Joyce and the trans-creation of the word," published in Threads in the Complex Fabric of Language. Linguistic and Literary Studies in Honour of Lavinia Merlini, ed. M. Bertuccelli Papi, A. Bertacca, S. Bruti (Pisa: Felici Editore, Pisa), 59-68. This is a collection of papers in honour of a retired colleague from the University of Pisa, addressed to a non-Joycean readership.

${ }^{2}$ See the following publications: Elena Di Giovanni, "Translations, Transcreations and Transrepresentations of India in the Italian Media", in Special Issue META, The Verbal, the Visual, the Translator, ed. Kaindl, K. and R. Oittinen N ${ }^{\circ} 53$ Vol. 1 (Les Presses de l'Université de Montreal, 2008), pp. 26-43; Gopinathan G., "Translation, Transcreation and Culture. Theories of Translation in Indian Languages," in Translating Others, ed. Hermans, Theo, Vol. 2 (St Jerome, Manchester, 2006), pp. 236-246; Lal, P., Transcreation, Writers Workshop (Calcutta, 1972); Mukherjee, Sujit, Translation as Recovery (Pencraft International, New Delhi, 2004); Trivedi, Harish, "Translating Culture vs Cultural Translation" (91 ${ }^{\text {st }}$ Meridian.Org 2005) 4: 1 (http://www.uiowa.edu/ iwp/91 ${ }^{\text {st }}$ ); and Trivedi, Harish, "Constructing the 'Orient': Translations from India into English in the Nineteenth Century", in Oxford History of Literary Translation in English, ed. Haynes, Kenneth and Peter France, V. 4, (Oxford University Press, Oxford 2006), pp. 480-498.
} 
This process allowed for a number of even radical changes to the original texts, which went well beyond the concept of "translation proper" as it was and is still perceived within translation studies. The transcreated text had to be totally fluent and, most significantly, it had to be fully understandable for its target audience [.... More recently, the concept of transcreation has been applied by Indian scholars to the study of translation from new perspectives, steeped in postcolonialism and sometimes loaded with sociopolitical connotations. ${ }^{3}$

The term "transcreation" describes some examples of the manipulative use of English, which can best be explained from a post-colonial perspective, and more specifically, the term helps to articulate one of Joyce's tactics in appropriating the language of the British whose domination over Ireland had tried to erase the native Gaelic language and culture. Joyce's use of language bears witness to the artist's rebellion against a colonization that had historically "translated" the Celtic heritage into a kind of Anglicization that Joyce, like the Stephen of A Portrait of the Artist as a Young Man, passionately resisted. An example of this resistance can be seen in the well-known passage in A Portrait where Stephen and the dean of studies discuss aesthetics: "One difficulty, said Stephen, in aesthetic discussion is to know whether words are being used according to the literary tradition or according to the tradition of the marketplace" ( $P$ 188). This anticipates the misunderstanding about the words "funnel" used by the dean of studies and "tundish" used by Stephen ( $P$ 188). The conversation highlights not only the painful gap between the English usurpers and their Irish victims, but also one important aspect of translation: the fact that even the same object changes when differently named. A "funnel" is not the same as a "tundish" because the two words are loaded with different memories and associations. Stephen feels the contradiction of speaking a language that does not belong to him:

The language in which we are speaking is his before it is mine. How different are the words home, Christ, ale, master on his lip and on mine! I cannot speak or write these words without unrest of spirit. His language, so familiar and so foreign, will always be for me an acquired speech. I have not made or accepted its words. My voice holds them at bay. My soul frets in the shadow of his language. (P 189)

Joyce's appropriation of the language of the invaders made it his own and made it recognizable as such. His manipulation of English was a means to make it his individual idiom, and he aimed at having any passage written by him attributable to him alone, as happens with Finnegans Wake, whose lan-

\footnotetext{
${ }^{3}$ Di Giovanni (2008), p. 33.
} 
guage has little to do with traditional English and challenges the very notion of semantics itself.

Joyce made his language memorable by adopting a variety of tactics. One of these was to distort the signifier, which he did in unusual ways. He would take not just unusual words but common, everyday English words and "transcreate" or transform them into strange, unexpected signs pointing to displaced objects. I have recently addressed what I mean by a "transcreated" word and a "displaced object" by tracing Joyce's use of the words "greenhouse" and "handkerchief" throughout Ulysses. ${ }^{4}$ I would like to reiterate here that Joyce's use of language is reminiscent of the process of translation as interpreted by Haroldo de Campos. ${ }^{5}$ In an essay on de Campos' poetics, Brazilian scholar Else Ribeiro Pires Vieira states that for de Campos translation is something that

unsettles the single reference, the logocentric tyranny of the original. Translation that has the devilish dimension of usurpation (de Campos 1997: 35-59); translation that disturbs linear flows and power hierarchies daemonic dimensions that coexist with the a priori gesture of tribute to the other inherent in translating and giving of one's own vitality to the other. Transcreation - the poetics that disrupts the primacy of the one model - a rupture and a recourse to the one and the other. ${ }^{6}$

I see Joyce's language in similar terms as subverting, even usurping, the original meaning, just like transcreation does for the Brazilian poet: "the poetics that disrupts the primacy of the one model." Considering Joyce's mode of writing, we can say that he disrupts the English model of language with determination.

Plurilingualism is one of the main characteristics of the language of Finnegans Wake, where the attempt to appropriate English and make it Joyce's personal language is brought to its extreme. Writing as translation, or playing on the transcreation of the word is a strategy to transform the language of the oppressor into Joyce's memorable language, but also a demonstration of Joyce's aim of showing the universality of a language.

\footnotetext{
${ }^{4}$ See my discussion of the two terms in Threads in the Complex Fabric of Language. Linguistic and Literary Studies in Honour of Lavinia Merlini, ed. M. Bertuccelli Papi, A. Bertacca, S. Bruti (Pisa: Felici Editore, Pisa), 59-68.

${ }^{5}$ De Campos, Haroldo, O Arco-Iris Branco: Ensaios de Literatura e Cultura, (Imago Editoria, Rio de Janeiro, 1997).

${ }^{6}$ Ribeiro Pires Vieira, Else, "Liberating Calibans. Readings of Antropofagia and Haroldo the Campos's Poetics of Transcreation", in Post-Colonial Translation: Theory and Practice, ed. Bassnett, Susan and Harish Trivedi, (Routledge, London, 1999), pp. 95-113.
}

Scientia Traductionis, n.8, 2010 
There is a passage at the beginning of Finnegans Wake that sounds quite obscure until it is read aloud: the scene occurs in a Park where a cad meets a stranger and is addressed with the following words: "Who ails tongue coddeau, aspace of dumbillsilly?" ( $F W$ 15.18) It was the French scholar Jacques Aubert, who first pointed out that the passage sounds like an angry expression in French: "Où est ton cadeau, espèce d'imbécile". " A few lines below in Finnegans Wake we find a less aggressive formulation: "Come on, fool porterfull, hosiered women blown monk sewer" ( $F W$ 16.4-5), which the first commentators 'translated' as: "comment vous portez-vous aujourd'hui mon blond monsieur". 8

Seamus Heaney, in a recent meeting with my students, ${ }^{9}$ quoted Joyce as the predecessor who had solved the dilemma that every Irish writer has to face: whether to use Irish ("my country tongue," said Heaney) or English ("my mother tongue"). Joyce had opened the way for Irish writers to use their mother tongue, English, but in their own personal, 'Irished' way. A translator himself, Seamus Heaney talked at length about the pleasure of translating and of "writing as translation" and pointed out that the very word "translation" carries the meaning of 'trancelation', a visionary, creative dimension that inevitably belongs to the process of translation.

I would like to close by proposing that, in transcreating the English word, Joyce succeeds in involving the reader in a trance-like adventure, by projecting the idea of translation into a universal activity that is at the basis of comprehension and peace among the peoples of the world.

\author{
Rosa Maria Bollettieri Bosinelli \\ bolletti@sslmit.unibo.it \\ University of Bologna at Forli
}

\footnotetext{
7 Aubert 1967: Aubert Jacques, 1967, "Finnegans Wake: Pour en finir avec les traductions?"(James Joyce Quarterly, Vol. 4, No. 3, pp. 217-22): 219.

${ }^{8}$ Campbell, Joseph and Henry Morton Robinson, A Skeleton Key to Finnegans Wake (Faber and Faber, London [1947] 1954), p. 46

${ }^{9}$ University of Bologna at Forli, June 13, 2008.
}

Scientia Traductionis, n.8, 2010 